ORIGINAL PAPER

Eur. J. Histochem

45: $259-265,200$

(C) Luigi Ponzio e figlio - Editori in Pavia

\title{
Morpho-histochemical changes in the liver and intestine of young giltheads (fish-nursery), Sparus aurata, L., induced by acute action of the anionic ten- sioactive alkylbenzene sulphonate
}

\author{
M. Rosety, F.J. Ordoñez, A. Ribelles, M. Rosety-Rodriguez, A. Dominguez, C. Carrasco, and \\ J.M. Rosety
}

Department of Morphological Sciences, School of Medicine, University of Cádiz, Spain

Accepted: 30/11/00

Key words: contamination, detergent, alkylbenzene sulphonate, fish, Sparus aurata, intestine, liver, histopathology, histochemistry

\section{SUMMARY}

In the present study we have assessed the effect on the survival and the morpho-histochemical changes in the liver and intestine of young giltheads (fishnursery), Sparus aurata, $L$., induced by acute action of the anionic tensioactive, alkyl benzene sulphonate (ABS). Firstly, the LC50 of ABS at 96 hours was found to be $0.6 \mathrm{mg} / \mathrm{L}$. Secondly, lots with 50 young giltheads (fish-nursery) were exposed to ABS concentrations of $0.5,1,3$ and $5 \mathrm{mg} / \mathrm{L}$, to obtain the surface tension value and exposure time required for $50 \%$ mortality of the specimens at each tested concentration. Exposure to ABS caused several forms of histopathological damage in the liver (the radial arrangement of hepatocytes was lost) and intestine (destruction of the structure of villi and increase in thickness of the other three layers). In addition, changes in bio-macromolecule components (proteins in general, siderophile proteins, neutral mucopolysaccharides, glycogen and acid mucopolysaccharides) were observed. The degree of these alterations was dependent upon the ABS concentration. These changes could have detrimental effects on the growth and survival of the species.

\section{INTRODUCTION}

Marine pollution is intimately related to socioindustrial development (Prat and Giraud, 1964; Swedmark et al., 1971). Tensioactives are significant components of several consumer products, such as laundry detergents, shampoos, toothpastes and cosmetics. About $70 \%$ of industrial production of tensioactives corresponds to anionic tensioactives (García Dominguez, 1986), the group to which ABS (alkylbenzene sulphonate) belongs.

Little is known about the damaging effect of detergents on marine fauna (Mahajan and Singh, 1972; Abel, 1974), in particular about histopathological and histochemical aspects. The aim of this work was firstly to determine the LC50 at $96 \mathrm{~h}$ and secondly to estimate the surface tension value and exposure time required for $50 \%$ mortality of the specimens resulting at each concentration of ABS. Finally, to examine histopathological alterations as well as the histochemical distribution of proteins (proteins in general, siderophile proteins) and carbohydrates (neutral mucopolysaccharides, glycogen and acid mucopolysaccharides) in two 
anatomical structures: liver and intestine. Selection of intestine was based on its direct contact with the tensioactive while the liver was chosen due to its indirect contact via the blood.

Research on the influence of the anionic surfactant ABS on gilthead Sparus aurata, $L$. was particularly appropriate because of its importance in the fishing industry and in fish farming (Arias et al., 1984). Besides, this species was very sensitive to any fall in the concentration of dissolved oxygen (Arias, 1976), which make it a useful tool in the study of pollutants that affect the oxygenation of the water.

In the present work we have chosen specimens younger than those employed by other authors (Ribelles et al., 1995 a, b, c; Rosety et al., 1997), in order to contribute to the limited knowledge about the effect of surfactants on the early life stages of giltheads Sparus aurata $L$.

Literature concerning the histopathology in aquatic species induced by detergents are circumscribed to gills in freshwater species (Schmid and Mann, 1961; Roy, 1988), as well as gills, intestine and liver-pancreas (Ribelles et al., 1995 a, b, c) and kidney and spleen (Rosety et al., 1997) in sea water species. Conventional histochemical techniques (PAS, alcian blue, bromophenol blue) are powerful and reliable tools to investigate the characteristics and distribution of carbohydrates and proteins in the digestive system of fishes (Elbal and Agulleiro, 1986; Domeneghini et al., 1998).

\section{MATERIALS AND METHODS}

250 young healthy giltheads (fish-nursery), fifteen days old, $1.8-2 \mathrm{~cm}$ long and weighing $0.5 \mathrm{~g}$, coming from a fish farm, were used in this study. Fifty specimens were used as controls and the remainder were divided into four lots, A, B, C and D. The four latter lots were exposed, respectively, to concentrations of $0.5,1,3$ and $5 \mathrm{mg} / \mathrm{L}$ of $\mathrm{ABS}\left(\mathrm{R}-\mathrm{CH}_{2}-\mathrm{C}_{6} \mathrm{H}_{6}\right.$ $\mathrm{SO}_{3} \mathrm{Na}$ with a purity of $80-85 \%$; Merck, Spain). Control fish were maintained under identical conditions without the addition of toxins.

Each group, consisting of fifty specimens, was maintained in a PVC tank containing 100 litres of sea water whose characteristics were: salinity $30 \%, \mathrm{pH} 7.4$, temperature $16-18^{\circ} \mathrm{C}$, surface tension $72.7 \mathrm{mN} / \mathrm{m}$, dissolved oxygen $8-8.6 \mathrm{mg} / \mathrm{L}$, hard- ness $100 \mathrm{mg} \mathrm{Ca} \mathrm{CO} / / 1$, and absence of heavy metals and contamination due to aerobic and anaerobic microorganisms.

The highest concentration we employed was lower than the one used by other authors (Okwuosa and Omoregie, 1995; Ribelles et al., 1995 a, b, c) but similar to the one those allowed by Spanish legislation in industrial toxic wastes. The lowest concentration we tested was similar to that allowed in drinking water for human consumption (Hernandez, 1992). To avoid variations in detergent concentrations, test solutions were changed every 12 hours. The bio-degradation occurring in this time is less than $10 \%$ of the initial concentration (Flores et al., 1980).

The LC50 causing death in a period of 96 hours was determined according to Loomis (1982) and Sprague (1976). Surface tension was measured using a Lauda TE 1 C/2 with SAE+KM3 tensiometer.

Once we noted the exposure time required for $50 \%$ mortality of the specimens at each concentration, we chose viable specimens from the same lot to examine histopathological and histochemical changes that appeared at this concentration. The fish killed by decapitation and then fixed in $10 \%$ $\mathrm{v} / \mathrm{v}$ formol buffered with $0.1 \mathrm{M}$ phosphate buffer, $\mathrm{pH}$ 7.2, dehydrated in increasing concentrations of alcohol, cleared with benzol and embedded in semisynthetic paraffin wax with a mean fusion point of $54-56^{\circ} \mathrm{C}$. Sections were cut at $5 \mu \mathrm{m}$.

Harris's haematoxylin and acetic eosin, Harris's haematoxylin-VOF (Gutierrez, 1967) and Gridley's reticulum stain (Gridley, 1951) were employed as general stains. The histochemical reactions made on carbohydrates and proteins in the liver (hepatocytes) and intestine (enterocytes and intestinal goblet cells) of young Sparus aurata, L. exposed to different concentrations of ABS are shown in Tables II, III and IV, respectively. It should be noted that the histochemical results are expressed as semiquantitative assessment of color intensities by independent scores of three investigators.

\section{RESULTS}

The LC50 of ABS at $96 \mathrm{~h}$ was found to be 0.6 $\mathrm{mg} / \mathrm{L}$. In Table I, the exposure times required for $50 \%$ mortality of the specimens $(120 ; 38 ; 16 ; 9)$ expressed in hours, and the surface tension values 
Table I

Exposure time required for 50\% mortality of the young Sparus aurata, $L$. and surface tension value resulting at each concentration of alkyl benzene sulphonate (ABS)

\begin{tabular}{ccc}
\hline ABS concentration $(\mathrm{mg} / \mathrm{L})$ & exposure time for $50 \%$ mortality (hour) & surface tension $(\mathrm{mN} / \mathrm{m})$ \\
\hline 0.5 & 120 & 68.9 \\
1 & 38 & 67.4 \\
3 & 16 & 65.5 \\
5 & 9 & 62.4 \\
\hline
\end{tabular}

$(68.9 ; 67.4 ; 65.5 ; 62.4)$ expressed in $\mathrm{mN} / \mathrm{m}$ were calculated at $0.5,1,3$ and $5 \mathrm{mg} / \mathrm{L}$ of ABS, respectively. No mortality occurred in the control lot.

Histopathological and histochemical changes observed were as follows.

\section{Liver}

Control: The sections obtained from untreated specimens revealed the normal histological and histochemical patterns of the digestive gland. Hepatocytes were cuboidal in form with welldefined limits and a central nucleus. They were arranged in radial strings around a central vein. Within these hepatocyte strings the biliary canaliculi could be seen. PAS reaction was moderately positive although it became negative after enzymatic digestion with $\alpha$-amylase PAS and diastase PAS, indicating the presence of glycogen. Levels of proteins in general were very weak while siderophile proteins were weakly positive.

Lot A (0.5 mg/L ABS): Hepatocytes were retracted and their radial arrangement was altered. They showed a moderate reactivity to PAS, similar to control, becoming negative after enzymatic digestion with $\alpha$-amylase PAS or diastase-PAS. The bromophenol blue technique was moderately positive, and siderophile proteins were weakly positive.

Lot B (1 mg/L ABS): Histopathological changes were very similar to those found at $0.5 \mathrm{mg} / \mathrm{L}$. PAS

Table II

Histochemical reactions on carbohydrates and proteins in the liver of young Sparus aurata, L. exposed to different concentrations of alkyl benzene sulphonate (ABS)

\begin{tabular}{|c|c|c|c|c|c|}
\hline REACTIONS & CONTROL & LOT A & LOT B & LOT C & LOT D \\
\hline $\begin{array}{l}\text { SCHIFF (Pearse, 1960) } \\
\text { Free aldehydes }\end{array}$ & 0 & 0 & 0 & 0 & 0 \\
\hline $\begin{array}{l}\text { PAS (McManus, 1948) } \\
\text { Adjacent hydroxyl groups }\end{array}$ & 3 & 3 & 0 & 4 & 4 \\
\hline $\begin{array}{l}\text { DIASTASE-PAS (Lillie and Greco, 1947) } \\
\text { Glycogen }\end{array}$ & 0 & 0 & $\mathrm{NP}$ & 0 & 0 \\
\hline $\begin{array}{l}\text { ALPHA-AMYLASE-PAS (Lillie and Greco, 1947) } \\
\text { Neutral mucosubstances and/or glycoproteins, excepting glycogen }\end{array}$ & en & 0 & NP & 0 & 0 \\
\hline $\begin{array}{l}\text { BROMOPHENOL BLUE-Hg (Chapman, 1971) } \\
\text { Proteins }\end{array}$ & 1 & 3 & 3 & 1 & 1 \\
\hline $\begin{array}{l}\text { HARTIG ZACHARIAS (Martoja and Martoja-Pierson, 1970) } \\
\text { SIDEROPHILE PROTEINS }\end{array}$ & 2 & 2 & 2 & 1 & 0 \\
\hline
\end{tabular}

Note: Lot A $(0.5 \mathrm{mg} / \mathrm{L} \mathrm{ABS})$; Lot B (1 mg/L ABS); Lot C (3 mg/L ABS) and Lot D (5 mg/L ABS).Results are expressed as semiquantitative assessment of color intensities by independent scores of three investigators. Estimated scale: 0 (negative); 1(very weak); 2 (weak ); 3 (moderate); 4 (strong) and NP (has no been performed). 
Table III

Histochemical reactions on carbohydrates and proteins in the intestine (enterocytes) of young Sparus aurata, $L$. exposed to different concentrations of alkyl benzene sulphonate (ABS)

\section{REACTIONS}

CONTROL LOTA LOTB LOTC LOT D

SCHIFF (Pearse, 1960)

Free aldehydes

PAS (McManus, 1948)

Adjacent hydroxyl groups

DIASTASE-PAS (Lillie and Greco, 1947)

Glycogen

ALPHA-AMILASE-PAS (Lillie and Greco, 1947)

Neutral mucosubstances and/or glycoproteins, excepting glycogen

BROMOPHENOL BLUE-Hg (Chapman, 1971)

Proteins

HARTIG ZACHARIAS (Martoja and Martoja-Pierson, 1970) SIDEROPHILE PROTEINS

$\begin{array}{lcccc}0 & 0 & 0 & 0 & 0 \\ 1 & 0 & 0 & 2 & 3 \\ 0 & \mathrm{NP} & \mathrm{NP} & 0 & 0 \\ 0 & \mathrm{NP} & \mathrm{NP} & 0 & 0 \\ 3 & 2 & 3 & 3 & 3 \\ 2 & 3 & 3 & 0 & 0\end{array}$

Note: Lot A $(0.5 \mathrm{mg} / \mathrm{L} \mathrm{ABS})$; Lot B $(1 \mathrm{mg} / \mathrm{L} \mathrm{ABS})$; Lot C (3 mg/L ABS) and Lot D (5 mg/L ABS). Results are expressed as semiquantitative assessment of color intensities by independent scores of three investigators. Estimated scale : 0 (negative); 1(very weak); 2 (weak ); 3 (moderate); 4 (strong) and NP (has not been performed).

reaction was negative. Proteins in general and siderophile proteins were similar to lot A.
Lot C (3 mg/L ABS): Histopathological features were similar to lots A and B. PAS reaction was

Table IV

Histochemical reactions on carbohydrates and proteins in the intestine (goblet cells) of young Sparus aurata, $L$. exposed to different concentrations of alkyl benzene sulphonate (ABS)

REACTIONS CONTROL LOTA LOTB LOTC LOTD

SCHIFF (Pearse, 1960)

Free aldehydes

$\begin{array}{ccccc}0 & 0 & 0 & 0 & 0 \\ 1 & 3 & 3 & 3 & 3 \\ 1 & 1 & 1 & 1 & 1 \\ 1 & 1 & 1 & 1 & 1 \\ 2 & 3 & 3 & 4 & 4 \\ 1 & 2 & 2 & 4 & 4 \\ + & + & + & + & +\end{array}$

PAS(McManus, 1948)

Adjacent hydroxyl groups

DIASTASE-PAS (Lillie and Greco, 1947)

Glycogen

ALPHA-AMILASE-PAS (Lillie and Greco, 1947)

Neutral mucosubstances and/or glycoproteins, excepting glycogen

ALCIAN - BLUE pH 2.5 (Martoja and Martoja-Pierson, 1970)

Carboxyl-rich glycoconjugates, sulphated or not

ALCIAN - BLUE pH 0.4 (Martoja and Martoja-Pierson, 1970)

Sulphated glycoproteins, strongly ionized

TOLUIDINE BLUE (Martoja and Martoja-Pierson, 1970)

metachromasia

Note: Lot A (0.5 mg/L ABS); Lot B (1 mg/L ABS); Lot C (3 mg/L ABS) and Lot D (5 mg/L ABS). Results are expressed as semiquantitative assessment of color intensities by independent scores of three investigators. Estimated scale: 0 (negative); 1(very weak); 2 (weak ); 3 (moderate); 4 (strong) and + (positive). 
strongly positive, becoming negative after enzymatic digestion. Proteins in general and siderophile proteins were very weak.

Lot D ( $5 \mathrm{mg} / \mathrm{L} \mathrm{ABS})$ : The radial arrangement of hepatocytes was completely lost and they were retracted. We also observed several cellular damages with wall breakings and lack of parenchyma. PAS reaction was strongly positive becoming negative after enzymatic digestion. Proteins in general were very weak and siderophile proteins were negative.

\section{Intestine}

For practical purposes, we considered intestine as the medium part of the digestive tract (Cataldi et al., 1987).

Control: The wall of the digestive tract was composed of mucosa, submucosa, muscularis and serosa.

Intestinal mucosa was composed of the epithelial layer, the lamina propria and the stratum compactum. Mucosal folds consisted of connective tissue cores covered by intestinal epithelium. Columnar cells or enterocytes were the more numerous of the epithelial lining cells and closely resemble those of higher vertebrates. These tall and cylindrical cells had striated, free borders (brush border or microvilli) and contained oval nuclei which were situated either centrally or toward the bases of the cells.

Intestinal mucous-secreting cells or goblet cells were interspersed among the columnar cells, being more numerous along the sides rather than on the crests or at the bases of the mucosal folds. They assumed the shape of a goblet due to the expansion of the distal region by their secretion. Goblet cell nuclei were found in the narrow basal portions of the cells.

Enterocytes showed a weak reactivity to PAS, becoming negative after enzymatic digestion with $\alpha$-amylase PAS or diastase PAS, suggesting the presence of glycogen. The bromophenol blue technique showed moderate presence of proteins in general. The Hartig Zacharias method showed weak presence of siderophile proteins.

Intestinal goblet cells showed a weak reactivity to PAS, which decreased to very weak after diastasePAS treatment, suggesting the presence of glycogen and neutral mucopolysaccharides. Alcian blue at $\mathrm{pH} 2.5$ showed a weak presence of carboxilated acidic mucopolysaccharides. Alcian blue at $\mathrm{pH} 0.4$ showed a very weak presence of sulphated, strongly ionized mucopolysaccharides. Toluidine blue revealed metachromasia, indicating the presence of sulphated acidic mucopolysaccharides.

Lot A $(0.5 \mathrm{mg} / \mathrm{L} \mathrm{ABS})$ : Villi were found to anastomose with each other forming a compact mass and losing their individual outline, while lamina propria could not be discerned clearly. Some areas of epithelium become detached. Submucosa was hypertrophied and muscular layer was thickened.

Enterocytes: PAS reaction was negative. Proteins in general were lower in comparison to control and siderophile proteins increased slightly with respect to control.

Intestinal goblet cells: PAS reactivity increased slightly with respect to control, although it decreased to very weak after enzymatic digestion. Alcian blue $(\mathrm{pH} 2.5$ and $\mathrm{pH} 0.4)$ stains increased slightly with respect to control. Toluidine blue revealed metachromasia.

Lot B (1 mg/L ABS): Morphological changes are similar to those found at $0.5 \mathrm{mg} / \mathrm{L}$.

Enterocytes: PAS reaction was negative. Proteins in general were similar to control and siderophile proteins increased slightly with respect to control.

Intestinal goblet cells: PAS reaction increased slightly respect to control, becoming very weak after enzymatic digestion. Alcian blue ( $\mathrm{pH} 2.5$ and $\mathrm{pH}$ 0.4) stains also increased slightly respect to control. Toluidine Blue revealed metachromasia.

Lot C (3 mg/L ABS): There was a complete detachment of epithelium in some areas. Submucosa was infiltrated by lymphocytes.

Enterocytes: PAS reaction increased slightly with respect to control, becoming negative after enzymatic digestion. Proteins in general were similar to control and siderophile proteins were negative.

Intestinal goblet cells: PAS reaction increased slightly with respect to control, becoming very weak after enzymatic digestion. Strong staining with Alcian Blue (pH 2.5 and $\mathrm{pH}$ 0.4). Toluidine blue revealed metachromasia.

Lot D ( $5 \mathrm{mg} / \mathrm{L}$ ABS): Histopathological features observed before were more pronounced. According to this, whole blocks of epithelia became detached and the mucosal cells were found in a highly desintegrated condition. We observed a more complete destruction of all the layers.

Enterocytes: PAS reaction increased strongly with respect to control, becoming negative after enzymatic digestion. Proteins in general were similar to control and siderophile proteins were negative. 
Intestinal goblet cells: PAS reaction increased slightly with respect to control, becoming negative after enzymatic digestion. They showed a strong reactivity to Alcian blue ( $\mathrm{pH} 2.5$ and $\mathrm{pH} 0.4$ ) stains. Toluidine blue revealed metachromasia.

\section{DISCUSSION}

Information regarding the effect of tensioactives on fish survival is very limited. The LC50 at $96 \mathrm{~h}$ obtained by Okwuosa and Omoregie (1995) in toothed carp, Aphyosemion gairdneri, L. using ABS was $25.11 \pm 8.4 \mathrm{mg} / \mathrm{L}$ and by Ribelles (1995 $\mathrm{a}, \mathrm{b}, \mathrm{c})$ in 6 months old giltheads using sodium dodecyl sulphate as anionic tensioactive was 6.1 $\mathrm{mg} / \mathrm{L}$. The LC50 at $96 \mathrm{~h}$ in the present study was found to be $0.6 \mathrm{mg} / \mathrm{L}$. From these results, it seems plausible that the latter concentration may be practically innocuous for adults of Sparus aurata $L$. but lethal for young Sparus aurata L. (fish-nursery), wich may endanger the survival of the species in the ecosystem in the long term.

It is thought that the fall in surface tension induced by surfactants is the main cause of death (Prat and Giraud, 1964; Mann, 1972). Surface tension values in our experiments reached as low as $62.4 \mathrm{mN} / \mathrm{m}$ and even lower values $(42.3 \mathrm{mN} / \mathrm{m})$ have been measured in the Bay of Cadiz (Flores et al., 1979). However, it has also been claimed that surface tension has little to do with the toxic effects of detergents on fishes (Marchetti, 1965; Muller, 1980).

The results of this work have shown a close relationship between tensioactive concentration and time required for $50 \%$ mortality of the specimens and surface tension value. According to Cairns and Scheier, (1962), Ribelles et al. (1995 a, b, c) and Rosety et al. (1997), the higher the concentration of the tensioactive is, the less the exposure time required for $50 \%$ mortality of the specimensis. The decrease of surface tension values when the concentration is increased was also reported by Ribelles (1995 a, b, c).

Independently of the mechanism that causes death, it was of interest to understand the histopathological lesions that appeared and, through histochemical methods, to appreciate alterations induced in bio-macromolecule components (proteins in general, siderophile proteins, neutral mucopolysaccharides, glycogen and acid mucopolysaccharides). Whichever the changes are that can provoke functional disorders in affected organs (i.e. damage to the mucosal epithelial cells could lead to the inhibition of both amino acid and sugar transport) they might be co-contributors to death.

Very little information is available on the histopathological and histochemical alterations produced in the liver and intestine of fishes exposed to ABS. Ribelles (1995 b, c), reported histopathological and histochemical changes produced by sodium dodecyl sulphate (SDS) in the same structures of giltheads (Sparus aurata, L.). In general terms, histopathological lesions as well as histochemical alterations described by this author coincided with ours, although he used a different anionic tensioactive, higher concentrations and older specimens.

The mechanisms by which tensioactives produce their effects have not been well understood (Helenius and Simmons, 1975). In agreement with Sprague (1976) and Mallat (1985). this work could not confirm a single cause of death. Rather, the decrease in surface tension, destruction of tissue, and effects at the organ levels may be co-contributors to the death of giltheads exposed to ABS.

We also conclude that using concentrations allowed by Spanish legislation, which are lower than those found in tests in the South Atlantic coast of Europe, severe histopathological lesions and histochemical alterations were produced in the liver and intestine of young giltheads (fishnursery). This is quite important since Sparus aurata, $L$. constitutes an important link in the food chain and its death via exposure to ABS may cause imbalance in the aquatic ecosystem.

\section{REFERENCES}

Abel P.: Toxicity of synthetic detergents to fish and aquatic invertebrates. J. Fish Biol. 6, 279-298, 1974.

Arias A.M.: Sobre la biología de la Dorada (Sparus aurata, $L$ ) de los esteros de la provincia de Cadiz. Inv. Pesq. 40, 201222, 1976.

Arias A.M., Drake P., and Rodríguez R.B.: Los esteros de las salinas de San Fernando (Cádiz, España) y el cultivo extensivo de peces marinos. In: INRA. L'aquaculture du Bar et des Sparidés. Institut National de la Recherche Agronomique. Paris, pp. 447-463, 1984.

Cairns J., and Scheier A.: The acute and chronic effects of sodium alkylbenzene sulphonate upon the pumpkiseed sun- 
fish (Lepomis gibbosus, L.) and bluegill sunfish (Lepomis macrochirus, $R$.). Proc. $17^{\text {th }}$ Ind. Waste Conf. Prude Univ. Eng. Ext. Ser, pp. 14-28, 1962.

Cataldi E., Cataudell S., Monaco G., Rossi A., and Tancioni L.: A study of the histology and morphology of the digestive tract of the seabream, Sparus aurata. L. Fish. Biol. 30, 135$145,1987$.

Chapman D.M.: Dichromatism of bromophenol blue, with an improvement in the mercuric bromophenol blue technic for protein. Stain Technol. 50, 25-30, 1971.

Domeneghini C., Panelle Straini R., and Veggetti A.: Gut glycoconjugates in Sparus aurata L. (Pisces, Teleostei). A comparative histochemical study in larval and adult ages. Histol. Histopath. 13, 359-372, 1998.

Elbal M.T., and Agulleiro B.: A histochemical and ultrastructural study of the gut of Sparus aurata (Teleostei). J. Submicrosc. Cytol. 18, 335-347, 1986

Flores V., Galan M., and Sales D.: Contaminación de las aguas de la Bahia de Cádiz (Il). Ensayos generales de calidad de las aguas. Ing. Quim. 125, 105-109, 1979.

Flores V., Galan M., and Sales D.: Contaminación de las aguas de la Bahia de Cádiz (IV). Ensayos de biodegradabilidad con dodecilsulfato sódico. Ing. Quim. 131, 81-111, 1980.

Garcia Dominguez J.J.: Tensioactivos y detergencia. Dossat, Madrid, 1986.

Gridley M.F.: A method of reticulum stain. Am. J. Clin. Pathol. 21,879-881, 1951 .

Gutierrez M.: Coloracion histologica para ovarios de peces, crustaceos y moluscos. Investigaciones pesqueras. 31, 265-271, 1967

Helenius A., and Simons K.: Solubilization of membranes by detergents. Biochem. Biophys. Acta. 415, 29-79, 1975.

Hernandez Muñoz A.: Depuración de aguas residuales. Servicio de Publicaciones de la Escuela de Ingenieros de Caminos de Madrid (U.P.M.), Madrid, 1992.

Lillie R.D., and Greco J.: Malt diastase and ptyalin in place of salive in the identification of glycogen stain. Stain Technol. $22,67-70,1947$

Loomis T.A.: Fundamentos de Toxicologia. Acribia, Zaragoza, 1982

Mahajan C.L., and Singh J.J.: Water pollution in relation to the biology of fishes. II. Histopathological changes induced by synthetic detergents in the gills of Heterpneustes fossilis. B. Proc. Symp. Envirom. Poll. 18-25, 1972.

Mallat J.: Fish gill structural changes induced by toxicants and other irritants: A statistical review. Can. J. Fish Aquat. Sci. 42, 630-648, 1985.

Mann H.G.: Toxicity and degradation of tensides in sea water. In: Marine pollution and sea life. FAO. Roma, pp. 248-249, 1972.
Marchetti R.: Relations entre la activite de surface, la composition chimique et la toxicite vis- a -vis de la vie acquatique des detergents de synthese. Conf. Int. des Arts. Chemiques, Paris, 1965

McManus J.F.A.: Histological and histochemical uses of periodic acid. Stain Technol. 23, 99-108, 1948.

Martoja R., and Martoja-Pierson M.: Tecnicas de histologia animal. Toray-Masson S.A., Barcelona, 176-208, 1970.

Muller R.: Fish toxicity and surface tension of non-ionic surfactants: investigations and antifoam agents. Journal Fisheries Biology. 16, 585-589, 1980.

Okwuosa V.N., and Omoregie E.: Acute toxicity of alkylbenzene sulphonate (ABS) detergent to the toothed carp, Aphyosemion gairdneri, L. Aquacult. Res. 26, 755-758, 1995.

Pearse A.G.: Histoquimica teorica y aplicada. Aguilar S.A., Madrid, 70-92, 1960.

Prat R., and Giraud A.: The pollution of water by detergents. O.E.C.D., Paris, 1964

Ribelles A., Carrasco C., and Rosety M.: Morphological and histochemical changes caused by sodium dodecyl sulphate on the gills of giltheads, Sparus Auratua L. Eur. J. Histochem. $39,141-148,1995 \mathrm{a}$

Ribelles A., Carrasco C., Rosety M., and Aldana M.: A histochemical study of the biological effects of sodium dodecyl sulphate on the intestine of giltheads seabream, Sparus Aurata L. Ecotoxicol. Environ. Saf. 32, 131-138, $1995 \mathrm{~b}$.

Ribelles A., Carrasco C., Rosety M., and Aldana M.: Morphological and histochemical changes on the liver and pancreas of giltheads, Sparus Auratus L., induced by acute action of the anionic detergent, sodium dodecyl sulphate. Histol. Histopathol. 10, 781-787, 1995c.

Rosety M., Ribelles A., and Carrasco C.: A morphologica study in the kidney and spleen of gilthead, Sparus aurata, $L$. caused by sodium dodecyl sulphate. Histol. Histopathol. 12 925-929, 1997.

Roy D.: Impact of detergents on the proteins histochemistry of various cell types of the gill epithelium of Rita rita. Ecotox. Environ. Saf. 15, 206-211, 1988.

Schmid O.J., and Mann H.: Action of a detergent (dodecyl benzene sulphonate) on the gills of trout. Nature. 192, 41-51, 1961

Sprague J.B.: The ABC's of pollutant bioassay using fish. In Biological methods for the assesment of water quality. (Eds. Cairn, J.Jr. and Dickson, K.L.) American Society for testing and materials. Philadelphia, pp. 6-30, 1976.

Swedmark M.B., Braaten B., Emanuelson E., and Granmo A.: Biological effects of surface agents on marine animals. Marine biology 9, 183-196, 1971. 